\title{
Herb-drug interaction in diabetes: a bane or a boon
}

\begin{abstract}
Diabetes one among the various life style disorders, ${ }^{1}$ has a pandemic existence in today's world. It affects the population, irrespective of the age, sex, religion, etc. A survey work done in Canada recently found that $75 \%$ people with diabetes used herbal supplements, vitamins etc. ${ }^{2}$ Overall the research indicates that people suffering from diabetes, are using herbal medicines in the form of a single herb or a polyherbal preparation, besides the prescribed medicine. These herbal formulations are considered to function as a nutritive supplement, nervine tonic or hypolipdemic agent. ${ }^{3}$ Even though these herbal supplements are claimed to be free from side effects but needs to be approved by FDA.
\end{abstract}

However, these herbs have their own pharmacological actions with the prescribed antidiabetic drug, which may be synergistic or antagonistic to the same. In the existing system, it is very difficult to control such concomitant usage of medicines of various types, as they are available for over the counter sale. Hence, an earnest attempt has been made here to review and analyze the positive as well as negative role of herbs and its modalities when they are used along with the contemporary medicine.
Volume I Issue 3 - 2014

Malagi KJ, Kamath M,Adiga SH

Department of Ayurveda, KMC Manipal University, India

Correspondence: Malagi KJ, Department of Ayurveda, KMC Manipal University, Kasturba Medical College, Manipal 576 40I, Karnataka state, India, Tel +91 944821568I, Email kjmalagi@gmail.com

Received: June 20, 2014 | Published: July 09, 2014

Keywords: diabetes, herb, herb drug interaction

Abbreviations: CAM, complementary and alternative medicine; FBS, fasting blood sugar; FDA, food and drug administration

\section{Introduction}

The system of Complementary and Alternative Medicine [CAM] is being used by around $80 \%$ of the present day global population as a supplement to the conventional medicine. ${ }^{4-7}$ The rising need and interest for holistic medical approach has contributed to various experimentations and establishments of the esteemed principles of the branch of herbal medicine, which is an integral constituent of the system of Complementary and Alternative Medicine.

As per the forecast made by WHO, the global market for herbal products would be about 5 trillion dollars by the year $2050 .{ }^{8}$ These herbs are either used as a supplement or as an alternative for prescription medicine. Mainly in life style disorders like diabetes. Bever, the author of the book "Medicinal plants in Tropical West Africa" has stated that there are more than 400 traditional plants possessing hypoglycemic action. ${ }^{9}$

Diabetes is one amongst the various lifestyle disorders which acts as a breeding ground for all the other life threatening diseases. It has become the major cause of premature illness in major countries due to cardio vascular disease, blindness and kidney failure etc. It is estimated that there are, presently around 143 million Diabetic patients in the world..$^{10}$ This may be doubled in $2030 .{ }^{11}$ The disease puts the immune system of the patients under significant threat, thus, favoring the invasion of the host body by various infectious diseases. It is quite common that people with diabetes use herbal supplements along with contemporary one. Studies have revealed the fact that Thirty five percent of the Americans who are suffering from diabetes use CAM. ${ }^{12}$ The patients under multiple systems of medication may have concerns about the possibility of the occurrence of polypharmacosis, thereby resulting in the interaction between drug molecules. The interactions may be apprehended and analyzed to be of drug-drug, herb-drug or food-drug varieties. In case of Drug-Drug Interactions the reaction mode is either pharmacodynamics or pharmacokinetics. ${ }^{13}$ While the drug-food interactions can affect bioavailability of a drug. For example the hypoglycemic effect of glipizide may be delayed slightly if taken with a meal versus 30-60minutes before a meal, although hemoglobin A1c (A1C) values are unaffected. ${ }^{14,15}$ But the Herb-drug interaction mechanism is still mysterious in the field of medicine. This can be studied similar to the features of modern pharmacological concepts. ${ }^{16}$

Out of many such herbs Bitter melon (BN. Momordica charantia L) is a popular plant of Asian origin. Different clinical trials, incorporating different kind and forms of the drug, like fresh fruit juice, seed extract and such others have been carried out, with variations in dosage modalities. ${ }^{17-19}$ It is used for lowering blood glucose levels in patients with diabetes mellitus. ${ }^{20}$ Trials reveal that the fruit extract of Bitter melon is effective in treating diabetes. ${ }^{21}$ In addition, experimental researches have demonstrated the positive outcome of bitter melon in complications of diabetes, like neuropathy and enteropathy, ${ }^{22}$ Cataract ${ }^{23}$ and nephropathy. ${ }^{24}$ While positive effects were seen on various parameters of lipid profile ${ }^{25-29}$ and also, the sap of the plant contains the principle constituent, the 'plant insulin' (a polypeptide) which reduces the blood glucose level in type 1 diabetes mellitus. ${ }^{30}$

Another most commonly used spice in Indian kitchen is Fenugreek (BN. Trigonella foenum-graecum L.). It contains Vitamin A, protein and fiber and is said to possess hypoglycemic and hypocholesterolemic properties. ${ }^{31}$ Food preparations which contain $10 \%$ fenugreek seed ${ }^{32}$ or extract ${ }^{33}$ or Fenugreek seed powder ${ }^{34}(\sim 10 \mathrm{~g} /$ day $)$ is said to be useful in reducing fasting blood sugar [FBS], triglycerides..$^{35}$ It also stimulates pancreatic action. ${ }^{36}$

Garlic (BN. Allium Sativum L) is one more spice which is routinely used in cooking. It acts as a hypoglycemic, hypocholesterolemic and hypolipidemic agent. ${ }^{37}$ A significant fall in blood glucose levels have been observed in patients using garlic along with chlorpropamide. ${ }^{38}$ It reduces blood sugar by producing active nitrogen compounds. ${ }^{39}$ It can 
also be used as an antioxidant and anti inflammatory agent. But, garlic is known to increase the bleeding tendency, when used with NSAIDs like aspirin. It may also react with vitamin $\mathrm{E}$ in high concentrations. ${ }^{40}$ A clinical trial suggests that garlic changes some pharmacokinetic variables of paracetamol. ${ }^{41}$ Garlic may act synergetically with anticoagulants like warfarin ${ }^{42,43}$ fluindione $e^{44}$ and reduce the efficacy of anti-AIDS drugs like saquinavir. ${ }^{45}$ Animal research shows that garlic preparations may enhance the bioavailability of propranolol. ${ }^{46}$

Onion (BN. Allium Cepa L) is more of a vegetable than an herb used in almost all the dietary preparations in India. The animal study reveals the hypoglycemic effect of onion..$^{47}$ Onion, when used as a dietary supplement, is proven to be useful in the management of type 1 and type 2 diabetes mellitus. ${ }^{48-50}$ The Study conducted by Tatfeng Y on animals showed significant increase in CD4 count. ${ }^{51}$ Experimental studies reveal that it reduces Cadmium induced kidney damage in rats. ${ }^{52}$ The oral administration of onion extract significantly decreases the level of T3, T4 hormones in the experimental animals. ${ }^{53}$ Onion has been reported to have anticoagulant as well as antioxidant properties. $^{54-57}$

Likewise, the leaves of Gymnema (BN. Gymnema Sylvestre, L) are used in Ayurveda, the Indian system of medicine to treat conditions like diabetes, obesity and such others. Gymnemic acid, an active principle of the plant has anti-obesity and antidiabetic properties, which helps in weight reduction. It can minimize the insulin dose in both Type 1 and Type 2 Diabetes. ${ }^{58-60}$ The plant extracts are found to arrest epinephrine-induced hyperglycemia. ${ }^{61}$ It also reduces Chromium reduced glycosylated hemoglobin (HbAlc). ${ }^{62}$ It is also observed to be hepato protective in the cases of injury caused as a result of radiation. ${ }^{63}$

Ginseng (BN. Panax ginseng \& P. quinquefolium) is a Chinese herb which possesses the additive pharmacological action in both insulin dependent and non dependent diabetes mellitus. ${ }^{64-66}$ The herb, ginseng may either decrease ${ }^{67}$ or increase ${ }^{68}$ the anticoagulant effect of warfarin. It may interact with Tricyclic antidepressants, other drugs that decrease seizure threshold and result in increased risk of seizures. ${ }^{69} \mathrm{It}$ also alters the action of Furosemide ${ }^{65}$ Estrogens, corticosteroids 8 Digoxin. ${ }^{70}$

The classics of Ayurveda elaborately explained the properties of the drug Guduchi- (Tinospora cordifolia Wild) as antipyretic and rejuvenating. They have also indicated it to be a remedy for diabetes. ${ }^{71}$ Animal experimental studies have proven that, extracts of Tinospora cordifolia could change lipid metabolism. It is of immense importance, as hyperlipidemia is one of the complications of the Diabetes. ${ }^{72}$ It also possesses antihepatotoxic ${ }^{73}$ as well as Immunomodulatory ${ }^{74}$ effects. Till now no such significant adverse event has been observed with the use of Guduchi in healthy individuals. ${ }^{75}$

Popularly known as a Ashwagandha in Ayurveda (BN. Withania somnifera) and commonly considered as the Indian ginseng, is having hypoglycemic, diuretic and hypocholesterolemic properties. ${ }^{76}$ The Studies indicate that Ashwagandha possesses stress reducing property and it acts synergetically when administered along with anxiolytic and anti-stressors. ${ }^{77}$ It also contains immunomodulatory, ${ }^{78,79}$ antioxidant ${ }^{80}$ properties.

Another herb Ivy gourd (BN. Cocciniaindica) is used in Ayurveda to treat Diabetes. The juice of the ripe fruit is used to treat Hyperglycemia, but the role of pharmacokinetics and Pharmacodynamics in this is unknown. ${ }^{81-83}$ Potential hypoglycemic action has been observed in administering a single oral dose of the Leaf of Coccinia. ${ }^{84}$
Jamun (BN. Eugeniajambolana) is an evergreen tree and its fruits are not too tasty, has a sharp sweet and astringent taste. As it has a low glycemic index, the seeds and seed powder of Jamun are used in the treatment of diabetes in Ayurveda. 85,86

\section{Discussion}

According to WHO, the 'herbal medicine' is defined as herbs, herbal materials, herbal preparations and finished herbal products, that contain as active ingredients parts of plants, or other plant materials, or combinations. ${ }^{87}$

WHO elaborately explains the criteria for assessing the safety, efficacy and quality of herbal medicines, utilizing the parameters like acute toxicity, organ targeted toxicity. Mutagenicity, genotoxicity, carcinogenicity as well as herb drug interaction. The main limitations of the herbal medicines are inadequate standardization, lack of quality specifications and lack of scientific data along with insufficient evidence regarding herb drug interactions. Even though no proper data available regarding the herb drug interaction, no attempt has been made to bring the same in the current medical academic curriculum. And also, information regarding the use of these products in the elderly population is almost nonexistent. ${ }^{88,89}$ It is absolutely impossible to differentiate herb-drug interactions from that of adverse drug effects. ${ }^{90-93}$ Herb drug interactions may be positive or negative in nature. But, it certainly influences the pharmacological action of a drug molecule in the body. It is difficult to assess the biochemical nature of the all the traditional medicinal plants and its interaction with the pharmaceutical agents of the contemporary medical system. Here the main issue of concern is its inadequate reporting system which makes it difficult to document an herb-drug interaction. Accreditation agencies like the US Food and Drug Administration (FDA) also do not have a clear agenda in this area, to fulfill the knowledge gap.

\section{Conclusion}

Today, even though millions of people are using herbal supplements with the assumption that 'natural products' are 'safe' for consumption, there is very little information available on the herb-drug interactions. In this regard, there is a need of public awareness which can be created by proper education and training of both the clinicians and the general public. And also, reliable information can be provided on authenticated websites. The governing agencies must issue proper guidelines for appropriate access and delivery of the reliable herbal medicines. Clinicians are advised to trace and pick up any information regarding usage of any herbal supplement or neutraceuticals along with prescribed medication by their patients. It should be made mandatory to document the adverse events, if any, with all the relevant information. Agencies like FDA, AYUSH and other food and drug regulatory boards must be vigilant about this emerging trend. This documented information can be a guideline for the clinicians, those who are using the anti diabetic drugs with or without the knowledge of the Indian system of medicine. The knowledge and implementation of the complementary and alternative medicine along with that of the antidiabetic drugs is the only way to provide a holistic approach in the treatment of diabetes.

\section{Acknowledgements}

None.

\section{Conflict of interest}

Author declares that there is no conflict of interest. 


\section{References}

1. Pappachan MJ. Increasing prevalence of lifestyle diseases: high time for action. Indian J Med Res. 2011;134(2):143-145.

2. Ryan EA, Pick ME, Marceau C. Use of alternative medicines in diabetes mellitus. Diabet Med. 2001;18(3):242-245.

3. Cefalu WT, Stephens JM, Ribnicky DM. Diabetes and Herbal (Botanical) Medicine. In: Benzie IFF, Wachtel-Galor S, editors. Herbal Medicine: Biomolecular and Clinical Aspects. 2nd ed. Boca Raton: CRC Press; 2011.

4. Astin JA. Why patients use alternative medicine: results of a national study. JAMA. 1998;279(19):1548-1553.

5. Druss BG, Rosenheck RA. Association between use of unconventional therapies and conventional medical services. JAMA. 1999;282(7):651-656.

6. Eisenberg DM, Davis RB, Ettner SL. Trends in alternative medicine use in the United States. 1990-1997: results of a follow-up national survey. JAMA. 1998;280(18):1569-1575.

7. Kuo GM, Hawley ST, Weiss LT, et al. Factors associated with herbal use among urban multiethnic primary care patients: a cross-sectional survey. BMC Complement Altern Med. 2014;4:18.

8. www.thehindubusinessline.in

9. Bever VO, Zahnd GR. Plants with oral hypoglycemic action. Q J Crude Drug Res. 1979;17(3-4):139-196.

10. Kingh H, Aubert RE, Herman WH. Global burden of diabetes, 19952025: prevalence, numerical estimates, and projections. Diabetes Care. 1998;21(9):1414-1431.

11. Harris MI, Flegal KM, Cowie CC, et al. Prevalence of diabetes, impaired fasting glucose, and impaired glucose tolerance in U.S. adults. The Third National Health and Nutrition Examination Survey, 1988-1994. Diabetes Care. 1998;21(4):518-524.

12. Yeh GY, Eisenberg DM, Davis RB, et al. Use of complementary and alternative medicine among persons with diabetes mellitus: results of a national survey. Am J Public Health. 2002;92(10):1648-1652.

13. Rowland M, Tozer TN. Clinical Pharmacokinetics: Concepts and Applications. 3rd ed. In: Williams \& Wilkins, editor. Baltimore, Md; 1995.

14. Wahlin-Boll E, Melander A, Sartor G, et al. Influence of food intake on the absorption and effect of glipizide in diabetics and in healthy controls. Eur J ClinPharmacol. 1980;18(3):279-283.

15. Berelowitz M, Fischette C, Cefalu W, et al. Comparative efficacy of a once-daily controlled-release formulation of glipizide and immediate-release glipizide in patients with NIDDM. Diabetes Care. 1994;17(12):1460-1464

16. Izzo AA, Borrelli F, Capasso R. Herbal medicine: the dangers of drug interaction. Trends Pharmacol Sci. 2002;23(8):358-391.

17. Leung L, Birtwhistle R, Kotecha J, et al. Anti-diabetic and hypoglycemic effects of Momordicacharantia (bitter melon): A mini review. Br J Nutr. 2009;102(12):1703-1708.

18. Grover JK, Yadav SP. Pharmacological actions and potential uses of Momordica charantia: A review. J Ethnopharmacol. 2004;93(1):123-132.

19. Rathi SS, Grover JK, Vats V. The effect of Momordicacharantia and Mucunapruriens in experimental diabetes and their effect on key metabolic enzymes involved in carbohydrate metabolism. Phytother Res. 2002;16(3):236-243.

20. Singh J, Cumming E, Manoharan G, et al. Medicinal Chemistry of the Anti-Diabetic Effects of MomordicaCharantia: Active Constituents and Modes of Actions. Open Med Chem J. 2011;5(Suppl 2):70-77.
21. Basch E, Gabardi S, Ulbricht C. Bitter melon (Momordica charantia): a review of efficacy and safety. Am J Health Syst Pharm. 2003;60(4):356-359.

22. Grover JK, Rathi SS, Vats V. Amelioration of experimental diabetic neuropathy and gastropathy in rats following oral administration of plant (Eugenia jambolana, Mucunapruriens and Tinosporacordifolia) extracts. Indian J Exp Biol. 2002;40(3):273-276.

23. Rathi SS, Grover JK, Vikrant V, et al. Prevention of experimental diabetic cataract by Indian ayurvedic plant extracts. Phytother Res. 2002;16(8):774-777.

24. Grover JK, Vats V, Rathi SS, et al. Traditional Indian anti-diabetic plants attenuate progression of renal damage in streptozotocin induced diabetic mice. J Ethnopharmacol. 2001;76(3):233-238.

25. Ahmed I, Lakhani MS, Gillett M, et al. Hypotriglyceridemic and hypocholesterolemic effects of anti-diabetic Momordicacharantia (karela) fruit extract in streptozotocin-induced diabetic rats. Diabetes Res Clin Pract. 2001;51(3):155-161.

26. Chaturvedi P, George S, Milinganyo M, et al. Effect of Momordicacharantia on lipid profile and oral glucose tolerance in diabetic rats. Phytothera Res. 2004;18(11):954-956.

27. Fernandes NP, Lagishetty CV, Panda VS, et al. An experimental evaluation of the antidiabetic and antilipidemic properties of a standardized Momordicacharantia fruit extract. BMC Complement Altern Med. 2007;7:29.

28. Jayasooriya AP, Sakono M, Yukizaki C, et al. Effects of Momordicacharantia powder on serum glucose levels and various lipid parameters in rats fed with cholesterol-free and cholesterol-enriched diets. J Ethnopharmacol. 2000;72(1-2):331-336.

29. Senanayake GV, Maruyama M, Shibuya K, et al. The effects of bitter melon (Momordicacharantia) on serum and liver triglyceride levels in rats. J Ethnopharmacol. 2004;91(2-3):257-262.

30. Welihinda J, Karunanayake EH. Extra-pancreatic effects of Momordicacharantia in rats. J Ethnopharmacol. 1986;17(3):247-255.

31. Srinivasan K. Fenugreek (Trigonellafoenum-graecum): A review of health beneficial physiological effects. Food Rev Intl. 2006;22(2):203-224.

32. Madar Z, Abel R, Samish S, et al. Glucose lowering effect of fenugreek in non-insulin dependent diabetics. Eur J of clin nutr. 1988;42(1):51-54.

33. Zahedi Asl S, Farahnaz S, Ghasemi A, et al. The Effect of Carbon Tetrachloride Extract of TrigonellaFoenumGraecum Seeds on Glycogen Content of Liver in Streptozotocin-Induced Diabetic Rats. Int J Endocrinol Metab. 2000;7(2):70-75.

34. Gopalpura PB, Jayanthi C, Dubey S. Effect of Trigonellafoenumgraecum seeds on the glycemic index of food: A clinical evaluation. Int $J$ Diab Dev Countries. 2007;27(2):41-45.

35. Kassaian N, Azadbakht L, Forghani B, et al. Effect of fenugreek seeds on blood glucose and lipid profiles in type 2 diabetic patients. Int $J$ VitamNutr Res. 2009;79(1):34-39.

36. Ajabnoor MA, Tilmisany AK. Effect of Trigonella foenum graceum on blood glucose levels in normal and alloxan-diabetic mice. $J$ Ethnopharmacol. 1988;22(1):45-49.

37. Thomson M, Al-Amin ZM, Al-Qattan KK, et al. Anti-diabetic and hypolipidaemic properties of garlic (Allium sativum) in stereptozotocininduced diabetic rats. Int J Diabetes Metabol. 2007;15:108-115.

38. Aslam M, Stockley IH. Interaction between curry ingredient (karela) and drug (chlorpropamide). Lancet. 1979;1(8116):607.

39. Sheela CG, Augusti KT. Antidiabetic effects of Sallyl cysteine sulphoxide isolated from garlic Allium sativum Linn. Indian J Exp Biol. 1992;30(6):523-526. 
40. Agarwal KC. Therapeutic actions of Garlic constituents. Med Res Rev. 1996;16(1):111-124

41. Gwilt PR, Lear CL, Tempero MA, et al. The effect of garlic extract on human metabolism of acetaminophen. Cancer Epidemiol Biomarkers Prev. 1994;3(2):155-160.

42. Burnham BE. Garlic as a possible risk for postoperative bleeding. Plast Reconstr Surg. 1995;95(1):213.

43. German K, Kumar U, Blackford HN. Garlic and the risk of TURP bleeding. Br J Urol. 1995;76(4):518.

44. Pathak A, Leger P, Bagheri H, et al. Garlic Interaction with Fluindione: A Case Report. Therapie. 2003;58(4):380-381.

45. Piscitelli SC, Burstein AH, Welden N, et al. The effect of garlic supplements on the pharmacokinetics of saquinavir. Clin Infect Dis. 2002;34(2):234-238

46. Asdaq SM, Inamdar MN. Pharmacodynamic and Pharmacokinetic Interactions of Propranolol with Garlic (Allium sativum) in Rats. Evid Based Complement Alternat Med. 2011;2011:824042.

47. Mathew PT, Augusti KT. Hypoglycaemic effects of onion, Allium cepa Linn. on diabetes mellitus - a preliminary report. Indian J Physiol Pharmacol. 1975;19(4):213-217.

48. Taj Eldin IM, Ahmed EM, Abd Elwahab HM. Preliminary Study of the Clinical Hypoglycemic Effects of Allium cepa (Red Onion) in Type 1 and Type 2 Diabetic Patients. Environ Health Insights. 2010;4:71-77.

49. Jain RC. Letter: Onion and garlic in experimental atherosclerosis Lancet. 1975;1(7918):1240.

50. Roman-Ramos R, Flores-Saenz JL, Partida-Hernandez G, et al Experimental study of the hypoglycemic effect of some anti-diabetic plants. Arch Invest Med (Mex). 1991;22(1):87-93.

51. Mirabeau TY, Samson ES. Effect of Allium Cepa and Allium Sativum on Some Immunological Cells in Rats. Afr J Tradit Complement Altern Med. 2012;9(3):374-379.

52. Suru SM. Onion and garlic extracts lessen cadmium-induced nephrotoxicity in rats. Biometals. 2008;21(6):623-633.

53. Eteng MU, Uduak IA. Interaction with iodine metabolism following ingestion of Allium Cepa and Allium Sativum by albino wistarrats. $J$ Nat Prod Plant Resour. 2012;2(3):344-349.

54. Slimestad R, Fossen T, Vagen IM. Onions: A source of unique dietary flavonoids. J Agric Food Chem. 2007;55(25):10067-10080.

55. Morimitsu Y, Morioka Y, Kawakishi S. Inhibitors of platelet aggregation generated from mixture of Allium species and/or S-alk(en)yl-L-cysteine sulfoxides. J Agric Food Chem. 1992;40(3):368-372.

56. McLellan DS, Jurd KM. Anticoagulants from marine algae. Blood Coagul Fibrinolysis. 1992;3(1):69-77.

57. Reddy BS, Rao CV, RivensonA. Chemoprevention of colon carcinogenesis by organosulfur compounds. Cancer Res. 1993;53(15):3493-3498.

58. Shanmugasundaram ER, Rajeswari G, Baskaran K, et al. Use of Gymnemasylvestre leaf extract in the control of blood glucose in insulin dependent diabetes mellitus. J Ethnopharmacol. 1990;30(3):281-294.

59. Baskaran K, Ahamath BK, Shanmugasundaram KR, et al. Antidiabetic effect of a leaf extract from Gymnemasylvestre in non-insulin-dependent diabetes mellitus patients. J Ethnopharmacol. 1990;30(3):295-300.

60. Bunyapraphatsara N, Yongchaiyudha S, Rungpitarangsi V, et al. Antidiabetic activity of Aloe vera L. juice. II. Clinical trial in diabetes mellitus patients in combination with glibenclamide. Phytomedicine. 1996;3(3):245-248.

61. Gupta SS. Inhibitory effect of Gymnemasylvestre (Gurmar) on adrenaline induced hyperglycemia in rats. Indian J Med Sci. 1961;15:883-887.
62. Nahas R, Moher M. Complementary and alternative medicine for the treatment of type 2 diabetes. Can Fam Physician. 2009;55(6):591-596.

63. Bhatia AL, Kamal R, Verma G, et al. Radioprotective role of gymnemic acid on mice: study on hepatic biochemical alterations. Asian J Exp Sci. 2008;22(3):427-432.

64. Vickers A, Zollman C. ABC of complementary medicine: herbal medicine. BMJ. 1999;319(7216):1050-1053.

65. Fugh-Berman A, Cott J. Dietary supplements and natural products as psychotherapeutic agents. Psychosom Med. 1999;61(5):712-728.

66. Yeh GY, Eisenberg DM, Kaptchuk TJ, et al. Systematic review of herbs and dietary supplements for glycemic control in diabetes. Diabetes Care. 2003;26(4):1277-1294

67. Janetzky K, Morreale AP. Probable interaction between warfarin and ginseng. Am J Health Syst Pharm. 1997;54(6):692-693.

68. Rosado MF. Thrombosis of a prosthetic aortic valve disclosing a hazardous interaction between warfarin and a commercial ginseng product. Cardiology. 2003;99(2):111.

69. Miller LG. Herbal medicinals: selected clinical considerations focusing on known or potential drug-herb interactions. Arch Intern Med. 1998;158(20):2200-2211.

70. O'Hara M, Kiefer D, Farrell K, et al. A review of 12 commonly used medicinal herbs. Arch Fam Med. 1998;7(6):523-536.

71. Gupta SS, Verma SC, Garg VP, et al. Anti-diabetic effect of Tinosporacordifolia part I. Effect on fasting blood sugar level, glucose tolerance and adrenaline induced hyperglycemia. Indian $J$ Med Res. 1967;55(7):733-745

72. Prince SMP, Menon VP, Gunasekaran G. Hypolipidaemic action of Tinosporacordifolia roots in alloxan diabetic rats. J Ethnopharmacol. 1999;64(1):53-57.

73. Peer F, Sharma MC. Therapeutic evaluation of Tinosporacordifolia on blood glucose and total lipid levels of normal and alloxan diabetic rats. Planta Med. 1992;58(2):131-136.

74. Atal CK, Sharma ML, Kaul A, et al. Immunomodulating agents of plant origin. 1. Preliminary screening. JEthnopharmacol. 1986;18(2):133-141.

75. Karkal YR, Bairy LK. Safety of aqueous extract of Tinosporacordifolia (Tc) in healthy volunteers: a double blind randomised placebo controlled study. IJPT. 2007;6(1):59-61.

76. Andallu B, Radhika B. Hypoglycemic, diuretic and hypocholesterolemic effect of winter cherry (Withaniasomnifera, Dunal) root. Indian J Exp Biol. 2000;38(6):607-609.

77. Archana R, NamasivayamA. Antistressor effect of Withaniasomnifera. $J$ Ethnopharmacol. 1999;64(1):91-93.

78. Dhuley JN. Adaptogenic and cardioprotective action of ashwagandha in rats and frogs. J Ethnopharmacol. 2000;70(1):57-63.

79. Rani G, Kaur K, Wadhwa R, et al. Evaluation of the anti-genotoxicity of leaf extract of Ashwagandha. Food Chem Toxicol. 2005;43(1):95-98.

80. Panda S, Kar A. Evidence for free radical scavenging activity of Ashwagandha root powder in mice. Indian $J$ Physiol Pharmacol. 1997;41(4):424-426.

81. Kamble SM, Jyotishi GS, Kamlakar PL, et al. Efficacy of Cocciniaindica W \& A in diabetes mellitus. J Res Ayurveda Siddha. 1996;(1-2):77-84.

82. Kamble SM, Kamlakar PL, Vaidya S, et al. Influence of Cocciniaindica on certain enzymes in glycolytic and lipolytic pathway in human diabetes. Indian J Med Sci. 1998;52(4):14-146.

83. Manjula S, Ragavan B. Hypoglycemic and Hypolipidemic effect of Cocciniaindica Wight \& Arn in alloxan induced diabetic rats. $\mathrm{Ans} \mathrm{Sci}$ Life. 2007;21(2):34-37. 
84. Platel K, Srinivasan K. Plant foods in the management of diabete mellitus: vegetables as potential hypoglycaemic agents. Nahrung. 1997;41(2):68-74.

85. Chopra RN, Chopra IL, Handa KL, et al. Indigenous Drugs of India. 2nd ed. Calcutta: UNDhar and Sons Pvt. Ltd; 1958:314-316.

86. Bhowmik D, Gopinath H, Kumar PB, et al. Traditional and Medicinal Uses of Indian Black Berry. Journal of Pharmacognosy and Phytochemistry. 2013;1(5):36-41

87. http://www.pharmainfo.net/reviews/herbal-medicine-and-itsstandardization

88. Norred CL, Zamudio S, Palmer SK. Use of complementary and alternative medicines by surgical patients. AANA J. 2000;68(1):13-18.

89. Gray SL, Hanlon JT, Fillenbaum GG, et al. Predictors of nutritional supplement use by the elderly. Pharmacotherapy. 1996;16(4):715-720.
90. Pittler MH, Ernst E. Systematic review: hepatotoxic events associated with herbal medicinal products. Aliment Pharmacol Ther 2003;18(5):451-471.

91. Setty AR Sigal LH. Herbal medications commonly used in the practice of rheumatology: Mechanisms of action, efficacy, and side effects. Semin Arthritis Rheum. 2005;34(6):773-784.

92. Naser B, Schnitker J, Minkin MJ, et al. Suspected black cohosh hepatotoxicity: no evidence by meta-analysis of randomized controlled clinical trials for isopropanolic black cohosh extract. Menopause. 2011;18(4):366-375.

93. Frazier TH, Krueger KJ. Hepatotoxic herbs: will injury mechanisms guide treatment strategies? Curr Gastroenterol Rep. 2009;11(4):317-324. 